\title{
"Kursen har självklart aktiv närvaro" - om löpande, muntlig examination på lektioner
}

\author{
Hans Färnlöf \\ Stockholms universitet
}

Utifrån empiriskt underlag i form av kursplaner och kursbeskrivningar från ett antal kurser i romanska språk diskuteras i dialog med befintliga nationella och lokala regelverk begreppet "aktiv närvaro" (definierat som löpande, muntlig examination under lektioner) ur ett trefaldigt perspektiv: myndighetsutövning, vetenskapligt tillvägagångssätt och pedagogisk teoribildning. I ett myndighetsperspektiv ifrågasätts i vilken grad likabehandling och förutsebarhet uppnås; vetenskapligt sett synas validiteten och reliabiliteten; på ett pedagogiskt plan reflekteras över formens kompatibilitet med olika nivåer av lärande. Genomgående påvisas ur samtliga dessa perspektiv svårigheter med att använda aktiv närvaro som examinationsform. I stället argumenteras för att använda aktiv närvaro som undervisningsform, i synnerhet med en uppläggning där formativ bedömning ingår. Artikeln är skriven i resonerande form och är tänkt att utgöra underlag för vidare reflektioner inom ramen för kursutveckling och akademiskt lärarskap i olika former.

Artikeln bygger på en längre rapport kring samma ämne (Färnlöf 2018).

Nyckelord: aktiv närvaro, myndighetsutövning, validitet, reliabilitet, formativ bedömning

Inom undervisningsvärlden har begreppet "aktiv närvaro" två besläktade - men samtidigt klart skilda - betydelser. Det kan å ena sidan beskriva en undervisningsform, där kursdeltagarna bedriver en viss aktivitet inom ramen för en kurs, samt å andra sidan en examinationsform, som består av löpande och, i första hand, muntliga examinationer under lektionspass. De pedagogiska övervägningar och didaktiska val som i mer eller mindre grad kan tänkas främja ett aktivt deltagande i den första betydelsen - aktiv närvaro som undervisningsform - tas inte upp i denna studie. Syftet med innevarande artikel begränsas till att problematisera användningen av aktiv närvaro som examinationsform. Tyngdpunkten kommer att ligga på de svårigheter denna examinationsform för med sig, och i viss mån kommer jag även att skissera på lösningar.

Jag kommer härvidlag att anlägga några perspektiv som alla utgör grundläggande parametrar för universitetsläraren: myndighetsutövning, vetenskapligt förhållningssätt och pedagogisk teoribildning. Denna tredelning täcker den högre undervisningens grundval, dvs. att inom ramen för en statlig myndighet bedriva genomtänkt undervisning som vilar på vetenskaplig grund. En inventering av kursbeskrivningar ${ }^{\mathrm{r}}$ vid Romanska och klassiska institutionen vid Stockholms

1 Kursbeskrivning är den benämning som vid Humanistiska fakulteten, Stockholms universitet, används för den kompletterande kursinformation som delges studenterna (jfr studiehandledning, kurs-PM m.m.).

*Författarkontakt: hans.farnlof@su.se

Artiklar och reflektioner är kollegialt granskade. Övriga bidragstyper granskas av redaktionen. Se www.hogreutbildning.se ISSN 2000-7558

(C)2018 Hans Färnlöf. This is an Open Access article distributed under the terms of the Creative Commons Attribution-NonCommercial 4.0 International License (https://creativecommons.org/licenses/by-nc/4.0/), allowing third parties to share their work (copy, distribute, transmit) and to adapt it, under the condition that the authors are given credit, that the work is not used for commercial purposes, and that in the event of reuse or distribution, the terms of this license are made clear.

Citation: Hans Färnlöf (2018) "Kursen har självklart aktiv närvaro" - om löpande, muntlig examination på lektioner», Högre utbildning, 8(2), 104-115. http://dx.doi.org/10.23865/hu.v8.1202 
universitet bildar empiriskt underlag för en diskussion som förs i dialog med styrdokument, tidigare reflektioner kring ämnet och forskning relaterad till detsamma. Med andra ord kommer jag att försöka inta en undersökande, ifrågasättande hållning i stället för den traditionella, individ- och erfarenhetsbaserade, som denna studies titel ger uttryck för.

Som undertiteln anger, åsyftas i denna studie med aktiv närvaro muntlig examination $i$ löpande undervisning, med andra ord en situation där en större eller mindre grupp examineras genom riktade frågor eller allmän diskussion, och där var och en i gruppen trots detta examineras individuellt². Skriftliga uppgifter som görs på lektion, som kontrollskrivningar, duggor eller liknande, tas inte upp specifikt i denna artikel, även om en del av resonemanget (t.ex. kring likabehandling vid omprov) kan appliceras även på dessa uppgifter. Obligatorisk närvaro, dvs. en rent fysisk närvaro där prestationen inte bedöms, ger i sin egenskap av kurskrav upphov till andra frågor än dem som behandlas i denna studie och tas därför inte heller upp.

\section{MYNDIGHETSPERSPEKTIVET}

De kursbeskrivningar som jag gått igenom bildar en första utgångspunkt för att diskutera aktiv närvaro ur ett myndighetsperspektiv, då de utgör den praktiska information som är tillgänglig för studenten och mer i detalj beskriver kursens genomförande jämfört med den mer allmänt hållna kursplanen. Skrivningar ur dessa kursbeskrivningar redovisas i detta avsnitt för att konkret illustrera i vilken grad och på vilket sätt idén om aktiv närvaro förklaras och integreras i kurserna. Inventeringen gjordes vårterminen 2016 och täcker delkurser inom ramen för kurser om 30 hp på grundnivå (dvs. från nybörjarnivå till kandidatnivå) i romanska språk vid Stockholms universitet: franska, italienska, portugisiska och spanska. Antalet delkurser uppgick då sammantaget till IO2 stycken. Dock fanns endast för franska samtliga kursbeskrivningar (32 delkurser) tillgängliga på universitetets lärplattform, medan ett antal saknades i italienska (I9 fanns tillhanda) och portugisiska (II tillhanda), samt ett större antal i spanska (I6 tillhanda). Materialet begränsades således till de sammanlagt 78 kursbeskrivningar som låg publicerade på lärplattformen.

När vi nu ska jämföra skrivningar i de genomgångna kursbeskrivningarna med kursplanerna, som ju ska innehålla "formerna för bedömning av studenternas prestationer" (Högskoleförordningen, I kap, $\$$ I5), kan först understrykas att aktiv närvaro inte förekom som examinationsform i någon kursplan ${ }^{3}$. Inte heller användes i dessa termen "aktiv närvaro" för att beskriva kursens innehåll eller undervisning. Trots detta angavs i kursbeskrivningarna för fjorton delkurser att man använde sig av någon slags löpande, examinerande, muntlig aktivitet: tre i franska, fyra i italienska, tre i portugisiska och fyra i spanska ${ }^{4}$. Som framgår av tabellen nedan motsvarar detta ungefärligen en av tio kurser i franska, en av fem kurser i italienska och en av fyra kurser i portugisiska och spanska.

2 Den individuella prestationen ska alltid kunna urskiljas vid examination enligt Regler för utbildning och examination på grundnivå och avancerad nivå vid Stockholms universitet (s. 18): "Eftersom betygssättning grundar sig på den enskilda studentens prestation, måste det vid all examination gå att urskilja den enskildes prestation (bidrag)."

3 Aktiv närvaro är heller inte del av de vid Humanistiska fakulteten, Stockholms universitet, accepterade examinationsformerna.

4 Kurserna numreras i ämnesordning enligt följande: kurs 1-3 (franska), kurs 4-7 (italienska), kurs 8-10 (portugisiska), kurs 11-14 (spanska). Ett urval av kurserna tas upp som exempel i denna studie. 
Tabell I: Genomgångna kursbeskrivningar (KBS) och förekomst av löpande, muntlig examination.

\begin{tabular}{|l|l|l|l|}
\hline Ämne & KBS & Aktiv närvaro & Procent \\
\hline Franska & 32 & 3 & $9 \%$ \\
\hline Italienska & I9 & 4 & $21 \%$ \\
\hline Portugisiska & II & 3 & $27 \%$ \\
\hline Spanska & I6 & 4 & $25 \%$ \\
\hline
\end{tabular}

Då cirka en femtedel av kursbeskrivningarna saknades, går det inte att bedöma exakt hur stor procent av samtliga delkurser som i realiteten använde sig av aktiv närvaro som examinationsform. Icke desto mindre bekräftade undersökningen att aktiv närvaro fortfarande användes som examinationsform i alla ämnen liksom att det i ett relativt stort antal fall existerade ett orådligt glapp mellan den formella kursplanen och den aktuella undervisningen'.

De befintliga skrivningarna bekräftade tyvärr även en annan bild, den som man beskriver i "Examination - en exempelsamling. Vanliga och mindre vanliga sätt att värdera studieresultat", angående examinerande seminarieverksamhet: "Klara kriterier och mål [...] saknas ofta i praktiken"' (s. 28). För de fjorton delkurser där man använde sig av någon slags löpande, examinerande, muntlig aktivitet, var det långt vanligare att den inte definierades. Det krävs t.ex. "aktivt deltagande vid lektioner" på Kurs 4, och det anges som en "självklarhet att obligatorisk närvaro och aktivt deltagande är en utgångspunkt för att bli godkänd" på Kurs I2 utan att det preciseras vad detta deltagande ska bestå av. I vissa fall förekommer en allmän beskrivning, som "aktiv närvaro genom övningar" (Kurs 6), "förberett deltagande vid lektionstillfällena och vid seminarierna" (Kurs 7) eller "deltagande i gruppdiskussioner" (Kurs I3).

Det kunde här ha varit till fördel för kursens genomförande att man specificerat vad aktiviteten består av. På så vis kunde ha tydliggjorts att det inte handlar om någon allmän aktiv närvaro utan om ett antal precisa examinationsformer7. I några fall preciseras aktiviteten mer tillfredsställande: "redovisa muntligt för de lästa texterna med utgångspunkt av instuderingsfrågorna" (Kurs го) eller "De muntliga proven består av instuderingsfrågor och korta textpresentationer som förbereds inför varje seminarium och sedan diskuteras i grupp eller gemensamt" (Kurs 3). Särskilt den sista beskrivningen ger en acceptabel vägledning till studenten. Majoriteten av beskrivningarna är dock i princip omskrivningar av begreppet "aktiv närvaro" och tillför inte någon väsentlig information till studenterna. Med andra ord vet då studenten inte vad denne förväntas prestera. Det kan t.o.m. finnas risk att det inte alltid framgår att lektionen (eller vissa delar av den!) faktiskt är ett prov. Man kan tillägga att det knappast är en slump att det inte framgår vad som gäller om man inte lyckas vara aktiv på lektionerna. Detta förefaller vara en naturlig konsekvens av den vaga begreppsapparaten: eftersom man inte har definierat vad aktiv närvaro är, eller hur den ska kunna bedömas, är det vanskligt att definiera vad aktiv närvaro inte är, eller hur den

5 Jag vill påminna om att dessa iakttagelser endast är giltiga för vårterminen 2016.

6 Detta är ett av de dokument som framställts av en stor samarbetsgrupp bestående av pedagogiskt sakkunniga representanter från en mängd högre lärosäten. Deras samlade erfarenhet och nyanserade reflektioner gör detta dokument till en värdefull källa att utgå ifrån. Dokumentet återfinns på sajten Kursutveckling.se och förkortas fortsättningsvis till "Examination...".

7 De benämningar som anges i Riktlinjer och mall för kursplaner vid Humanistiska fakulteten, Stockholms universitet (s. 14) är "salstentamen, skriftlig inlämningsuppgift i form av ... [precisera, t ex uppsats, PM, hemtentamen, praktikrapport, loggbok, rapport från...] muntlig redovisning i form av ... [precisera, $\mathrm{t}$ ex ventilering av egen uppsats, opposition på andras uppsats $\mathrm{m}$ fl.], peer review, praktiskt prov i form av ... [precisera], gestaltande uppgift [precisera, t ex rollspel...] multimodal... visuell... laboration.” 
ska kompletteras. I kursbeskrivningarna framgår genomgående inte heller enligt vilka kriterier den ska bedömas och endast i ett fall (Kurs 3) hur denna viktas mot övriga examinationsmoment.

Överlag kan man alltså utifrån kursbeskrivningarna inte få annat än en mycket ungefärlig bild av den aktiva närvaron som kursinslag. Detta trots att tydlig information till studenten är grundläggande för att man ska kunna säkerställa en god undervisning i pedagogiskt hänseende. I ett rättssäkerhetsperspektiv kan man därtill inte nog understryka vikten av att det ska framgå vad som ska bedömas, hur detta ska bedömas och i vilken grad detta ska bedömas ${ }^{8}$. Det är här ytterst tveksamt om man genom kursbeskrivningen uppnår en av grundstenarna i universitetslärarens myndighetsutövning, nämligen att verksamheten ska vara förutsebar (kursplanen garanterar förvisso en förutsebarhet, men denna är av mycket allmänt slag, t.ex. att det kommer att ingå 2-3 muntliga prov på kursen).

Ytterligare en central frågeställning rörande aktiv närvaro, ur ett myndighetsperspektiv, gäller den likabehandling som ska råda enligt den s.k. Objektivitetsprincipen (som är reglerad i grundlagen: en myndighet ska behandla alla lika inför lagen ${ }^{9}$ ). Vid en hastig anblick verkar aktiv närvaro uppfylla detta krav. Själva idén med formen är inkluderande: läraren öppnar för ett brett deltagande och ställer frågor till hela gruppen. Men hur skicklig är läraren egentligen på att hantera en gruppdynamik, där ofta ett mindre antal kursdeltagare monopoliserar diskussionen? Visar läraren samma attityd mot samtliga kursdeltagare? Vem eller vilka tilldelas frågorna? Ställs lika svåra frågor till alla? Får verkligen alla samma chans att visa sina kunskaper?

Svaren på dessa frågor kan nog variera, liksom det praktiska genomförandet. Redan den muntliga formen (t.ex. medelst den klassiska muntliga tentan) öppnar för viss variation i utformningen. När Nilsson (2000, s. 206) framför sina konkreta erfarenheter av muntlig examination, konkluderar han att den är "extremt svår att standardisera". I sina reflektioner kring sin egen muntliga examination noterar han också att flera studenter ansåg både utformning och bedömning orättvis. När man därtill ska genomföra muntlig examination $i$ seminarieform, finns det, som vi ska se, goda skäl att tillstå, som görs i "Examination - en exempelsamling..." (s. 8), att det "krävs betydligt mer planering och en genomtänkt strategi för att alla deltagande studenter ska få en rättvis och korrekt bedömning".

Denna strategi gäller inte bara de enskilda seminarierna, utan hela uppläggningen av kursen. Eftersom aktiv närvaro oftast innebär en kontinuerlig prestation, innebär detta också att studenten bedöms under sin lärprocess (jag återkommer längre fram till de pedagogiska implikationerna av detta). Hur viktas dennes prestationer i förhållande till kursens progression? För att ta ett konkret exempel: bör ett föredrag som hålls i inledningen av kursen bedömas på samma sätt som det som hålls i slutet av en kurs som sträcker sig över en hel termin? En uppenbar konsekvens är att den student som gör sin uppgift tidigt riskerar att missgynnas, och då föreligger inte längre likabehandling. Det summativa inslaget inträffar vid olika tidpunkter för olika studenter, och dessa tidpunkter kan på många språkkurser som sträcker sig över tid medföra skilda förutsättningar för studenterna (inte minst kan lärarens återkoppling, om den ges inför klassen, fungera formativt för kommande föredragshållare medan den i huvudsak fungerar summativt för den som genomfört föredraget).

8 Jag tillämpar här den definition av rättssäkerhet som presenteras av Universitetskanslerämbetet i Rättssäker examination, s. 13: "förutsebarhet i rättsliga angelägenheter".

9 Regeringsformen, 1 kap, 9 \$: ”Domstolar samt förvaltningsmyndigheter och andra som fullgör offentliga förvaltningsuppgifter ska i sin verksamhet beakta allas likhet inför lagen samt iaktta saklighet och opartiskhet. Lag (2010:1408)." 


\section{Hans Färnlöf}

En sista aspekt av myndighetsutövning som kort kan nämnas rör dokumentationen, vilken är önskvärd att upprätta vid all form av examination. Skriftliga prov producerar i sig underlag för dokumentation. För att ytterligare stärka rättssäkerheten bör även muntlig examination dokumenteras i någon form. Genom detta säkerställer man att underlaget finns tillhanda både för en säkrare bedömning och eventuell omprövning. Emellertid framgår det inte i någon av kursbeskrivningarna att de muntliga prestationerna på något sätt kommer att dokumenteras. Det torde heller inte vara vanligt att diskussioner spelas in. En någorlunda tillfredsställande lösning på detta kunde vara att föra omedelbara anteckningar (gärna utifrån en tydlig bedömningsmall, som tar upp olika bedömningsområden, prestationsnivåer och viktning), vilket skulle leda till att examinationen blir rättssäkrare.

Efter denna genomgång av en första aspekt av problematiken kring aktiv närvaro, kan man identifiera olika svårigheter med att använda löpande, muntlig examination på lektionerna. Dessa kan möjligen avhjälpas eller åtminstone reduceras genom tydligare skrivningar, genomtänkt viktning eller inspelning av examination. Detta hindrar dock inte att aktiv närvaro öppnar för en rad problem ur ett myndighetsperspektiv. I detta sammanhang kan påminnas om att universitet är en statlig myndighet och dess anställda är statstjänstemän. För att utöva sin verksamhet måste en myndighet följa lagar och förordningar. Den ansatsen verkar inte kunna uppnås när man ser till den genomgångna dokumentationen. Man kan anta att denna situation inte är specifik för just romanska språk vid Stockholms universitet, utan att liknande omständigheter föreligger även i andra ämnen och vid andra lärosäten ${ }^{\text {10 }}$.

\section{DET VETENSKAPLIGA FÖRHÅLLNINGSSÄTTET}

För varje forskare är validitet och reliabilitet självklara parametrar att integrera i det arbete som denne utför. Vad sker om man intar detta förhållningssätt till aktiv närvaro? Till att börja med är en simpel faktor som kan påverka validiteten helt enkelt frågan var lärarens hjälp slutar och var studentens svar börjar. Det kan vara svårt att alltid skilja studentens prestation från lärarens eller kurskamraters inspel. Problemet är väl förklarat i "Examination..." (s. 8):

om någon student inte tycks behärska en fråga är det lätt hänt att en annan student eller läraren själv fyller i, som man kanske skulle göra i ett vanligt samtal. Om man inte ser upp kan man då göra en felaktig bedömning av den enskildes kunskaper och förståelse.

Man kunde till detta citat lägga påverkan av lärarens kroppsspråk när en student utvecklar ett svar (t.ex. ett nickande som visar att studenten är på rätt spår). Liknande indicier förekommer vanligtvis inte vid skriftliga prov.

Att examinera i diskussionsform öppnar således för en viss oklarhet, men huvudfrågan vad gäller validitet torde ändå vara vad löpande, muntlig examination i grupp huvudsakligen prövar: "Är det möjligen fråga om blyghet, utåtvändhet eller fantasi i stället för förmåga att tala som mäts?” undrar t.ex. Ericsson (1989, s. 399) angående muntlig språkfärdighet. Med andra ord, i vilken grad mäts personen respektive prestationen? Man kan förstås hävda, att dessa aspekter med nödvändighet överlappar varandra. Veltcheff och Hilton (2003, s. I24) anmärker att det som

10 En snabb Google-sökning på "aktiv närvaro" + "examination" ger vid handen att begreppet används på kurser från vitt skilda områden och vid allehanda högre lärosäten. Under en workshop vid Stockholms universitet den 2 december 2016 kunde konstateras att problematik kring närvaro var väl spridd inom olika ämnen och fakulteter, vilket åtminstone är en indikation på att problemet inte är begränsat till språkämnena. 
särskiljer muntlig kompetens är att elevens personlighet spelar en betydande roll, till exempel om denne är blyg eller utåtvänd. Men detta förhållande medför icke desto mindre konsekvenser att begrunda om man vill begagna sig av aktiv närvaro, där den tillbakadragne studenten uppmanas att göra en lika bra prestation under en gruppdiskussion som den oblyge. Här finns en uppenbar risk, vilken uttrycks koncist i "Examination..." (s. 8): "Den som ogillar att ta plats i en grupp, inför en lärare, kan komma att undervärderas. Även det motsatta är tänkbart."

Extern påverkan är påtagligare vid examination i seminarieform än vid enskild examination, eftersom det på ett annat sätt skapas ett konkurrerande examinationsmoment. Detta kan vara hämmande för studenten: vem har det bästa svaret på instuderingsfrågan? vad är min kommentar värd efter att klassens briljantaste student har gjort (ännu) en perfekt utläggning? Den enskildes styrkor eller svagheter korrelerar direkt med de andras och påverkar examinationen kontinuerligt. Ju mer framstående en viss student är, desto större blir svårigheten för de andra att visa sina kunskaper; ju mer vissa studenter tagit kommandot i gruppen, desto svårare blir det för andra att ta plats. Gruppdynamiken kan således göra att de som känner sig säkrare framstår som ännu kunnigare medan det omvända gäller för dem som är osäkra. Tankegången summerar här socialpsykologins resultat som visar att man visst kan prestera bättre i grupp, men endast om man behärskar ämnet (Nilsson 1993).

Men kanske är det bra med konkurrens? Inte om man får tro Veltcheff och Hilton (2003), som i sin presentation av tjugo grundläggande påståenden om examination listar följande två punkter: "vägra att skapa tävling" respektive "respektera inlärarens personlighet". Detta påstående stöds av ett underbyggt resonemang hos Wiliam och Leahy (20I5, s. 177-210), enligt vilket forskningen visar att konkurrerande målinriktad undervisning allmänt ger sämre resultat än både individ- och gruppbaserad målinriktad undervisning. Dessutom kan tilläggas att förväntade studieresultat på en kurs sällan nödvändiggör eller underförstår någon form av konkurrens. Det närmaste vi kommer en sådan situation är de meningsutbyten som ska examineras för att säkerställa att studenten kan argumentera för eller emot, debattera och dylikt. Dessa lärandemål förekom dock på ett fåtal av de kurser som utgjort det empiriska underlaget för denna studie.

För att uppnå en högre validitet krävs andra lösningar. Tornberg (2009, s. 198) anlägger här ett välkommet helhetsperspektiv då hon först konstaterar svårigheten med att prestera muntligt i eller inför en grupp - "Att stå inför en församling och tala innebär för många människor ett nästan oöverstigligt stresstillstånd ${ }^{\text {In" }}$ - för att därefter föreslå att dessa personer faktiskt bör få slippa att göra uppgiften i denna form. Även i "Examination..." (s. 9) föreslås en lösning:

Ett sätt att hantera att vissa studenter inte tar plats är att kombinera den muntliga gruppexaminationen med ett skriftligt, individuellt underlag. Om studenterna i förväg har fătt lämna in enskilda skrivuppgifter kan läraren dels ställa riktade frågor med utgångspunkt i eventuella oklarheter, dels skapa sig en fylligare bild av den som inte kommer till sin rätt i ett gruppsamtal.

11 På sajten www.terapisnack.com hittar man t.ex. detta närmast desperata inlägg: ”Jag sitter här och är nervös inför i morgon. Går en kurs på $15 \mathrm{hp}$ på SU, på deltid, och har första seminariet i morgon. [...] Aktiv närvaro krävs nämligen. Jag är såå rädd för att inte ha något att säga, och för att jag ska säga något dumt och korkat och få alla att tycka att jag är så himla osmart och inte förstår någonting. [...] Jag funderar på att hoppa av kursen till och med, trots att ämnet är himla intressant.” Inlägget är från den 5 september 2011. Vi kan naturligtvis inte veta om det är ett autentiskt inlägg, men det torde framstå som karakteristiskt för studenters ängslan inför diskussion i grupp. 


\section{Hans Färnlöf}

Upplägg med löpande, muntliga examination i grupp kan möjligen vara mer försvarbart på kurser där antalet kursdeltagare är begränsat. I "Examination..." (s. 27) skriver man följande om sådan examination:

Storleken på seminariegruppen varierar, men det är förstås önskvärt med ett begränsat antal deltagare. Detta dels för att man som lärare ska hinna med att göra en rättvis bedömning av var och en, dels för att studenter kan uppleva det svårt att tala inför en alltför stor grupp.

Kurser med färre deltagare kan tyckas underlätta för kursdeltagarna att (våga) vara aktiva. Dock kan även deltagande i mindre grupper vara besvärligt för enskilda studenter, som helt enkelt inte trivs att prata inför grupp - oavsett om denna av andra kan anses som "liten" eller "lagom stor".

Det anges också i citatet ovan att en mindre grupp öppnar för en rättvis bedömning. Epitetet "rättvis" påminner oss åter om myndighetsperspektivet, som vi redan diskuterat, och för oss vidare in på reliabiliteten ${ }^{\text {12 }}$. Allmänna faktorer som kan påverka denna, enligt Tornberg (I989, s. 2IO) - "oklara instruktioner i provet, tidspress vid testtillfälle och testpersonens psykiska eller fysiska tillstånd" -, tycks alla prominenta när aktiv närvaro används. Exempel på oklarhet har redan diskuterats i genomgången av kursbeskrivningar; tidspressen är inbyggd i den muntliga diskussionen, där svarstiderna är korta eller mycket korta, vilket kan utgöra ett problem för vissa studenter ${ }^{13}$; det psykiska tillståndet påverkas närmast ovillkorligen av det sociala sammanhanget.

Just denna sista faktor syns mig central. En grundläggande tanke med aktiv närvaro som examinationsform är att det förväntas att studenten ska kunna visa sina kunskaper utan att påverkas nämnvärt av klassrumssituationen. Ett typexempel är att diskutera en text som alla har läst, vilket också förekom i flera av instruktionerna för de kursbeskrivningar vi gått igenom. Detta kan måhända tyckas vara en "naturlig" del av undervisningen, men det är tillika viktigt att se att aktiviteten är tänkt att äga rum i en specifik situation, där speciella förfaranden, omständigheter och förhållningsregler gäller ${ }^{14}$. Studenten förväntas svara på frågan på ett visst sätt, under vissa former, på en viss tid och under en viss tid. Den praktiska lektionssituationen blir alltså det medium genom vilket kunskapsutbytet ska ske, vilket ställer stora krav på tydligheten: det allmänna sammanhanget måste vara fullkomligt transparent för alla parter, informationen måste vara adekvat och komplett, utan tvetydigheter, man ska vara öppen för olika förhållningssätt, kunna resonera och observera, vara kritiskt medveten om kontexten, kunna resonera kritiskt, agera, ha likadana möjligheter m.m. Kan alla dessa parametrar uppfyllas? Kanske är ett av grundproblemen med aktiv närvaro, på ett teoretiskt plan, att vi kräver redovisning av interna kompetenser i ett starkt externt sammanhang, ett kunskapsutbyte där speciella former av socialitet tillåts påverka både validitet och reliabilitet (se Illeris 2009, s. 8-Io)?

Det finns således allmänna, till viss del externa parametrar som kan försvåra muntlig examination i grupp. Själva prestationen i sig kan även den vara svår att mäta, bortsett från i vilken grad den påverkas av till exempel gruppdynamik och tidspress. Ericsson (1989, s. 399-400)

12 Kan betonas att det inte föreligger någon motsättning mellan dessa ingångssätt: konstruerar man en genomtänkt kurs med tydliga examinationsformer och transparenta kriterier, har man uppfyllt flera delar av myndighetsuppdraget samtidigt som man format en kurs som ger studenterna bättre möjligheter att kunna genomföra den liksom för läraren att bedöma studenternas prestationer.

13 Examination...", s. 10: "Studenter som presterar bäst med längre betänketid än vad som är möjligt i ett samtal kan underprestera vid en muntlig gruppvis examination."

14 Cf. "learning and thinking are always situated in a cultural setting and always dependent upon the utilization of cultural resources" (Bruner 2009, s. 161). 
noterar att den muntliga formen i sig gör att stoffet blir större och friare, och därmed svårare att bedöma: "Flervalsproven går bra att rätta objektivt medan fritt tal [...] bedöms mer subjektivt." Det är långt svårare att bedöma aktivt deltagande jämfört med föredrag och specifik typ av argumentation, menar också Veltcheff och Hilton (2003, s. I24). Tillkommer den speciella omständighet att när en fråga besvarats av en student i grupp är den så att säga avhandlad. Eftersom det inte är möjligt att bedöma kunskaperna i just denna fråga hos dem som inte svarar, krävs alltså att man ställer likvärdiga frågor till övriga kursdeltagare (vilket förefaller mycket svårt, $\mathrm{i}$ synnerhet om gruppen är stor).

Man kunde här invända att den aktiva närvaron är kontinuerlig, och således ger många tillfällen till löpande examination. Läraren får på detta sätt ett samlat material att bedöma. Detta är förvisso sant, men icke desto mindre föreligger svårigheter med denna bedömning, i synnerhet om lärarens tanke är att göra ett tvärsnitt av studentens prestationer, vilket ofta är fallet på de genomgångna delkurserna där man förutsätts vara "aktiv"'s. Men prestationerna kan variera mycket över kursens gång. Om man gör en samlad bedömning av studentens insatser under hela kursen, snarare än att mäta den specifika nivå som denne uppnått i slutet av kursen, dvs. om man använder löpande summativ examination i stället för en avslutande sådan, hur ska man vikta det som sades i början, mitten respektive slutet på kursen? Om därtill en viktning sker, är denna tydlig för studenten? Hur väl kan egentligen läraren bedöma varje student individuellt utifrån sina samlade intryck och minnesbilder? Svårigheten påpekas i "Examination..." (s. Io): "I fallet med muntlig gruppexamination är studenternas prestationer flyktiga. Det kan vara svårt att i efterhand analysera och begrunda prestationer som inte finns nedtecknade." Hur skicklig är läraren att inte tidigt kategorisera studenten i ett visst fack ("bra", "svag" osv.) och i vilken grad påverkar detta lärarens attityd till studenten fortsättningsvis? Bedömer läraren studenten sammantaget objektivt eller påverkas hen av de första intrycken studenten skapat?

Sett till de olika slag av svårigheter som är förbundna kan generellt uppmanas till en översyn av den aktiva närvarons roll i enstaka kurser. I en del av de delkurser som kommenterades inledningsvis kan denna examinationsform faktiskt framstå som mer eller mindre överflödig. Om man konsulterar motsvarande kursplaner, kan man för det första fråga sig om lärandemålen förutsätter muntlig gruppaktivitet eller ens passar för gruppaktivitet. På de genomgångna kurserna anges till exempel endast ett mindre antal studieresultat $i$ form av aktiva verb som förutsätter interaktion (delta i samtal, debattera osv. ${ }^{16}$. För det andra kan man faktiskt undra om aktiv närvaro behövs som examinationsmoment på vissa kurser, eller om den snarare står med på traditionsenlig basis. I det genomgångna materialet finns till exempel Kurs 6 där man, utöver aktiv närvaro i olika former, har 2-4 skriftliga uppgifter samt 3-6 inlämningsuppgifter. Mängden examinationsmoment verkar här indikera att aktiv närvaro kunde strykas (alternativt att övriga examinationsmoment bör begränsas).

15 En alternativ uppläggning, där man "betar av" en rad skilda moment under kursens gång, faller utanför detta resonemang. En sådan löpande examination förutsätter dock att momenten är isolerade från varandra och inte återkommer längre fram på kursen (eftersom de då skulle examineras flera gånger på en och samma kurs). Alternativt kan finnas ett flertal examinationstillfällen där samma lärandemål examineras, men det bör då tydligt framgå att betyget svarar mot den främsta prestationen och inte är en sammanvägning av samtliga prestationer.

16 I de fall där sådana lärandemål förekommer är det givetvis naturligt att anordna någon form av muntlig examination i seminarieform eller mindre grupp. Jfr "Examination...”, s. 10: "Om lärandemålen handlar om argumentation och att kunna diskutera givna problem kan examinationen med fördel ges formen av ett samtal studenterna emellan." 


\section{Hans Färnlöf}

\section{EN INLEDANDE DIALOG MED PEDAGOGISK TEORI}

Hittills har vi hållit oss kring den praktiska undervisningssituationen, i ett juridiskt och allmänvetenskapligt sammanhang. Det kan också vara värt att föra ett bredare, teoretiskt förankrat resonemang för att utröna vilka antaganden som aktiv närvaro vilar på och vilka konsekvenser detta får för den pedagogiska grundsynen. Något om detta nämndes redan angående studentens förväntade prestation i klassrumssammanhanget, och jag ska här kortfattat utveckla tankegången genom att koppla mina egna reflektioner till diskussionen om formativt lärande och olika nivåer av inlärning.

Min utgångspunkt är att aktiv närvaro, såsom den vanligen uppfattas, grundar sig på premissen att kunskap framför allt är en kognitiv produkt, som bildas genom tankemässiga konstruktioner. Man ersätter, kompletterar och utvecklar gradvis sina kunskaper och färdigheter inom olika typer av föreställningsmässiga ramar alternativt skapar nya, mer eller mindre omformade och utvidgade ramar i transformativa skeenden. Detta senare görs kanske främst genom att studera problem och försöka lösa dem, och på så vis konfrontera sina rådande uppfattningar, kunskaper och angreppssätt med fall, frågor, texter m.m. Dessa kognitiva processer är vid aktiv närvaro tänkta att ske genom interaktion, och i det avseendet vilar genomförandet på ett konstruktivistiskt antagande ${ }^{17}$. Som närvarande är du aktiv och interagerar, och på så sätt formas och omformas kunskapen.

Denna aktivitet kan synas naturlig, liksom den traditionella undervisningsformen som just beskrevs. Emellertid diskuteras här aktiv närvaro som examinationsform. Detta betyder att man i själva formandet och omformandet av kunskapen samtidigt examinerar, dvs. utför en summativ bedömning. Men är det rimligt att betygsätta en student som genomgår en lärprocess? "Sätt aldrig betyg på elever medan de fortfarande lär sig", skriver Wiliam och Leahy (20I5, s. 2I), ett motto de tillskriver den inflytelserike amerikanske pedagogen Alfie Kohn. Man kunde argumentera att lektionen är tänkt att bära frukt längre fram. Om så är fallet, sker inom aktiv närvaro något av en hopblandning av ett konstruktivistiskt anslag, som till sin essens är formativ, och summativ bedömning av de resultat som presenteras portionsvis under kursen.

Man kan också fråga sig vilken typ av lärande, och därmed vilken typ av prestation, man över huvud taget kan förvänta sig under en lektion med aktiv närvaro. Jag utgår här från de olika nivåer av lärande som skissas av Illeris (2009), och som delvis utgår från Piaget:

- $\quad$ kumulativ - isolerad kunskap som endast är giltig inom en viss kontext (till exempel lära sig huvudpersonens namn i en bok)

- $\quad$ assimilativ - ny kunskap läggs till ett befintligt mentalt schema (till exempel efter att ha lärt sig ett språks olika genuskategorier notera vilket genus ett specifikt ord har)

- ackommodativ - något nytt lärs in som tvingar inläraren till att bryta upp och omforma befintliga tankemönster (till exempel att förstå att konjunktiv är ett modus och inte ett tempus)

- transformativ - djupgående förändring av inläraren själv (till exempel att genom ny kunskap se på världen på ett annat sätt)

17 Kegan (2009, s. 44): "Constructivism recognizes that reality does not happen preformed and waiting for us merely to copy a picture of it. Our perceiving is simultaneously an act of conceiving, of interpreting." 
Vilken roll kan aktiv närvaro spela för lärande på dessa olika nivåer? Det kumulativa och det assimilativa lärandet kräver betydligt mindre kognitiv ansträngning än de andra nivåerna av lärande, liksom en enklare och kortare process: den nya informationen integreras genom befintliga kanaler i befintliga kategorier. Detta lärande kan således uppnås i det interaktiva sammanhang som en lektion utgör.

Men högre utbildning syftar också till att inläraren ska omvandla sina tankesätt och därigenom utvecklas som individ i dialog med lärandet och de nya kunskaperna. Dessa två nivåer - dvs. den ackommodativa och den transformativa - betonas särskilt av vissa teoretiker, och då i synnerhet den omvälvande transformativa dimensionen av lärande. Inlärning ska till exempel enligt Jarvis (2009:25) leda till en djupgående förändring av individen ("a continually changing (or more experienced) person"). Det tycks mig som om ett sådant lärande med nödvändighet kräver en långtgående process som innehåller mer eftertanke och får utrymme över ett större tidsspann. Det räcker till exempel inte att det genomgår Kolbs (1984) inlärningscykel: erfarenhet $\rightarrow$ reflektion $\rightarrow$ konceptualisering $\rightarrow$ experimentering. Till dessa steg torde man behöva lägga värdering, nyansering, memorering, reflektion osv., och kanske måste processen upprepas ett flertal gånger.

Då en sådan process kräver tid, kan den näppeligen produceras inom ramen för en lektionstimme. En lektionsaktivitet kan säkerligen vara en del av uppbyggnaden av ett sådant lärande, men då framför allt i ett framåtsyftande perspektiv: diskussion och interaktion i seminarieform hjälper kursdeltagaren att finna modifierade eller nya sätt att angripa olika fenomen. Att denna nivå ska uppnås på själva lektionen är däremot kanske väl mycket begärt (inte minst sett till de svårigheter som kan komma ur det specifika institutionella sammanhang som lektionen utgör). Förvisso lär många lärare och studenter känna igen att det kan skapas många stunder av "aha-upplevelser" under en lektion. Likväl kräver dessa insikter bearbetning och assimilering enligt till exempel Kolbs schema.

När man examinerar genom löpande prov kan sålunda hävdas att man till stor del bryter in i en komplex lärprocess, och därmed delexaminerar studenten på väg fram till att denne uppnår en djupare kunskap. Alternativt förutsätter läraren att dessa processer till största delen redan ägt rum inför lektionen. Frågan är då om läraren har givit det stöd som behövts för att eleven ska ha kunnat genomföra denna process samt om det är rimligt att resultatet av processen ska kristalliseras under muntlig examination i grupp. Kunskapen är sällan praktiskt förpackad i en begränsad enhet som enkelt placeras inom de egna ramarna för befintlig kunskap. Likt arbetsgruppen för examination vid Stockholms universitet (20IO, s. 2I) kan man därför ställa sig frågan: även om jag kan bedöma den aktiva närvaron (med hjälp av god planering, genomtänkt viktning, tydliga kriterier, perfekt frågefördelning, exemplariskt bemästrande av gruppdynamiken osv.), bör jag göra det? Den kritiska diskussion som jag fört leder till slutsatsen att man i normalfallet inte ska använda aktiv närvaro som examinationsform. Det förefaller naturligare att inkludera den aktiva närvaron i läraktiviteter som leder fram till djupare kunskap och därmed till slutgiltig examination (detta förutsätter givetvis dels ett tydligt, formativt anslag, dels att de avslutande, betygsgrundande uppgifterna ger tillräckligt underlag för en korrekt betygsbedömning utifrån de förväntade studieresultaten). Ett sådant upplägg, med aktiv närvaro som formativ undervisningsform, skulle enligt en forskningssammanställning av Wiliam och Leahy (2015) kunna utgöra en effektiv förändring för att uppnå bättre lärande ${ }^{18}$.

18 ”Forskningsresultaten visar faktiskt att användning av formativ bedömning i klassen kan ge bättre resultat avseende elevprestationer än någon annan förändring som lärare gör” (Wiliam \& Leahy 2015, s. 28). 


\section{Hans Färnlöf}

\section{AVSLUTANDE ANMÄRKNINGAR}

Genom att konfrontera en traditionell undervisningsform - i det här fallet den klassiska "aktiva närvaron" - med pedagogiska infallsvinklar och formella myndighetskrav, har ett antal perspektiv kunnat skönjas i denna studie. Ur samtliga perspektiv som tagits upp, vare sig det handlat om pedagogik, juridik, praktik eller teori, framstår aktiv närvaro som, om inte olämplig, i varje fall ytterst problematisk som examinationsform. För de kurser som examineras med aktiv närvaro kan en allmän rekommendation därför vara att läraren reflekterar över hur väl den fungerar med hänsyn till de perspektiv som tagits upp i denna artikel. Här är särskilt viktigt att tydligt skilja på examination och undervisning. Ett flertal av resonemangen i denna studie utmynnar i slutsatsen att aktiv närvaro passar utmärkt som undervisningsform, i synnerhet om den genom riktad, konstruktiv återkoppling ger studenten bättre förutsättningar att nå kursens lärandemål. Dock är det viktigt att fastslå att den problematik som identifierats inte låter sig sammanfattas i kategoriska slutsatser. Varje enskild kurs tarvar sina egna lösningar. Det kan mycket väl hända att man för en viss kurs väl kan hävda lämpligheten i att inkludera en examinerande, "aktiv" närvaro med hänsyn tagen till kursens innehåll och utformning. Denna studie ska därför i första hand läsas som en reflektion, och inte som en instruktion.

Hur en kursuppläggning ska genomföras på bästa sätt är en fråga för lärare och pedagogiskt ansvariga vid våra institutioner. Min förhoppning är att de tankar och de perspektiv som diskuterats i denna studie ska kunna utgöra en inspiration eller ett delunderlag för kursutveckling i synnerhet kring examination inom högre utbildning. En möjlig väg att gå är då att anta det vetenskapliga förhållningssätt vi universitetslärare på ett självklart sätt antar i forskningssammanhang, och som även varit vägledande för denna studie. På så sätt kan man idka ett akademiskt lärarskap och verka för en mer initierad dialog kring pedagogisk utveckling. Avslutningsvis vill jag slå ett slag för att fler kreativa miljöer skapas inom akademien för sådana utbyten. Flera studier (Bolander Laksov, McGrath \& Silén 2007; Hadar \& Brody 20IO; Jones 20IO) har visat på hur en öppen och kollegial miljö kan skapa ett gynnsamt forum för att den pedagogiska diskussionen ska kunna ta plats inom akademien och vara lika självklart närvarande - och aktiv! - som det vetenskapliga seminariet.

\section{FÖRFATTARPRESENTATION}

Hans Färnlöf är docent i franska vid Stockholms universitet och före detta ämnesansvarig, utbildningsledare och studierektor. Efter sin avhandling om Maupassants noveller har han publicerat ett stort antal artiklar, huvudsakligen om fransk I80o-talslitteratur, samt ansvarat för en rad workshoppar om pedagogisk utveckling. Han undervisar i första hand på litteraturkurser.

\section{REFERENSER}

Bolander Laksov, K., McGrath, C. \& Silén, C. (2007). Scholarship of Teaching and Learning - the Road to an Academic Perspective on Teaching. Medical Education Guide, 6, 2-15.

Bruner, J. (2009). Culture, mind, and education. In K. Illeris (red.), Contemporary Theories of Learning: Learning Theorists ... In Their Own Words (s. 159-168). Routledge.

Ericsson, E. (1989). Undervisa i språk: språkdidaktik och språkmetodik. Studentlitteratur.

Färnlof, H. (2018). Projektet ALTAN (ALternativ Till Aktiv Närvaro) - observationer och reflektioner kring examination på grundnivån i Romanska språk vid Stockholms universitet. Stockholm: Rapporter om undervisning och lärande i högre utbildning (no. 2018:1). https://doi.org/10.17045/sthlmuni.7352753.

Hadar, L. \& Brody, D. (2010). From isolation to symphonic harmony: Building a professional development community among teacher educators. Teaching in Higher Education, 16, 1641-1651.

Högskoleförordningen (SFS 1993:100). Stockholm: Utbildningsdepartementet. 
Illeris, K. (2009). A Comprehensive Understanding of Human Learning. In K. Illeris (red.), Contemporary Theories of Learning: Learning Theorists ... In Their Own Words (s. 7-20). Routledge.

Jarvis, P. (2009). Learning to be a person in society: learning to be me. In K. IlIeris (red.), Contemporary Theories of Learning: Learning Theorists ... In Their Own Words (s. 21-34). Routledge.

Jones, J. (2010). Building pedagogic excellence: learning and teaching fellowships within communities of practice at the University of Brighton. Innovations in Education and Teaching International, 47:3, 271-282.

Kegan, R. (2009). What "form" transforms? A constructive-developmental approach to transformative learning. In K. Illeris (red.), Contemporary Theories of Learning: Learning Theorists ... In Their Own Words (s. 35-52). Routledge.

Kolbs, D. (1984). Experiential learning: experience as the source of learning and development. Englewood Cliffs.

Kungörelse om beslutad ny regeringsform (SFS 1974:152). Stockholm: Justitiedepartementet.

Myndigheten för nätverkande och samarbete inom högre utbildning. (2010). Examination - en exempelsamling. Vanliga och mindre vanliga sätt att värdera studieresultat. Hämtad från http://www.kursutveckling.se

Nilsson, B. (1993). Individ och grupp: En introduktion till gruppsykologi. Lund: Studentlitteratur.

Nilsson, G. (2000). Muntlig examination: analys av en examinationsform. H. A. Larsson (red.) Den reflekterande medborgaren (s. 201-216). Jönköping: Jönköping Univ. Press.

Stockholms universitet (2010). Allmänna råd för examination vid Stockholms universitet. Stockholm: Stockholms universitet.

Stockholms universitet (2015). Regler för utbildning och examination på grundnivå och avancerad nivå vid Stockholms universitet. Dnr SU FV-1.1.2-0900-15S. Stockholm: Stockholms universitet.

Stockholms universitet. (2015). Riktlinjer och mall for kursplaner vid Humanistiska fakulteten, Stockholms universitet. Dnr SU FV-1.1.2-1092-15. Stockholm: Stockholms universitet.

Tornberg, U. (2015). Språkdidaktik. Gleerups.

Universitetskanslerämbetet. (2017). Rättssäker examination. Tredje upplagan. Stockholm: Universitetskanslersämbetet.

Veltcheff, C. \& Hilton, S. (2003). L'évaluation en FLE. Hachette.

Wiliam, D. \& Leahy, S. (2015). Handbok i formativ bedömning. Natur och Kultur. 